Article

\title{
Effects of the Diet Inclusion of Common Vetch Hay Versus Alfalfa Hay on the Body Weight Gain, Nitrogen Utilization Efficiency, Energy Balance, and Enteric Methane Emissions of Crossbred Simmental Cattle
}

\author{
Wuchen Du ${ }^{1}$, Fujiang Hou ${ }^{2, *}$, Atsushi Tsunekawa ${ }^{3, * \mathbb{D}}$, Nobuyuki Kobayashi ${ }^{3}$, \\ Toshiyoshi Ichinohe ${ }^{4}$ and Fei Peng ${ }^{5,6}$ \\ 1 The United Graduate School of Agricultural Sciences, Tottori University, Tottori 680-8550, Japan; \\ duwuchen1990@126.com \\ 2 State Key Laboratory of Grassland Agro-Ecosystems, Key Laboratory of Grassland Livestock Industry \\ Innovation, Ministry of Agriculture, College of Pastoral Agriculture Science and Technology, \\ Lanzhou University, Lanzhou 730020, China \\ 3 Arid Land Research Center, Tottori University, Tottori 680-0001, Japan; \\ kobayashi.nobuyuki@alrc.tottori-u.ac.jp \\ 4 Faculty of Life and Environmental Science, Shimane University, Matsue 690-8504, Japan; \\ toshi@life.shimane-u.ac.jp \\ 5 International Platform for Dryland Research and Education, Tottori University, Tottori 680-0001, Japan; \\ pengfei@tottori-u.ac.jp \\ 6 Key Laboratory of Desert and Desertification, Northwest Institute of Eco-Environment and Resources, \\ Chinese Academy of Sciences, Lanzhou 730000, China \\ * Correspondence: cyhoufj@lzu.edu.cn (F.H.); tsunekawa@tottori-u.ac.jp (A.T.); Tel.: +86-0931-8913047 (F.H.); \\ +81-0857-23-3411 (A.T.)
}

Received: 10 October 2019; Accepted: 14 November 2019; Published: 18 November 2019

check for updates

Simple Summary: Nitrogen utilization efficiency and enteric methane emission from ruminants remain the primary concerns when developing ruminant feed globally. Nitrogen utilization efficiency is the ratio of retained nitrogen in body tissue to the total nitrogen intake, which is the main factor in the body weight gain of ruminants, and usually range from $15 \%$ to $40 \%$. The methane emissions of ruminants are an inevitable by-product when feeds have been fermented in the rumen and represents a $2 \%$ to $12 \%$ loss of diet energy. The low nitrogen utilization of ruminants can damage air quality and lead to soil nitrification and acidification, whereas high methane emissions from ruminants can increase global warming. Our study investigated the effects of two kinds of legumes (alfalfa and common vetch) with different levels ( $20 \%$ vs. $40 \%$ ) of total dry matter allowance on body weight gain, nutrient digestibility, nitrogen utilization efficiency, and enteric methane emissions for crossbred Simmental cattle. Our results suggested that nitrogen utilization efficiency and methane emissions are significantly affected by the legume species and proportions. These results could be beneficial for the development of regional or national ruminant feeding systems, thereby improving nitrogen utilization efficiency and reducing methane emissions.

Abstract: A low nitrogen utilization efficiency (NUE, the ratio of retained $\mathrm{N}$ to $\mathrm{N}$ intake) and high methane $\left(\mathrm{CH}_{4}\right)$ emissions of ruminants can lead to potentially high diet protein wastage and directly contribute to global warming. Diet manipulation is the most effective way to improve NUE or reduce $\mathrm{CH}_{4}$ emissions. This study investigated how replacing oat hay with alfalfa hay (AH) or common vetch hay $(\mathrm{CVH})$ with different proportions $(20 \%(20)$ and $40 \%(40)$ of the total dry matter (DM) allowance) affects the body weight gain (BWG), NUE, and $\mathrm{CH}_{4}$ emissions of crossbred Simmental cattle. The forage dry matter intake (DMI) and the total DMI of cattle fed on a CVH40 diet were 
significantly higher than the values for those fed on AH20 or AH40 diets $(p<0.05)$. There were no differences in the BWG for the four treatments observed, however, nutrient digestibility significantly decreased in the AH40 diet as compared with the AH20 diet $(p<0.05)$. The NUE was significantly lower in $\mathrm{AH} 40$ than in $\mathrm{CVH} 20$. The $\mathrm{CH}_{4}$ emissions were significantly lower for the $\mathrm{CVH} 40$ diet than with the AH20 diet $(p<0.05)$. Our findings suggest that a $20 \% \mathrm{AH}$ and $40 \% \mathrm{CVH}$ substitution for oat hay are the optimal proportions to maintain the BWG, NUE, nutrient digestibility, and reduce the $\mathrm{CH}_{4}$ emissions of crossbred Simmental cattle. Overall, $\mathrm{CVH}$ has a greater potential to reduce $\mathrm{CH}_{4}$ emissions than $\mathrm{AH}$.

Keywords: leguminous forage; digestibility; energy utilization efficiency; nitrogen metabolism; dryland

\section{Introduction}

The impacts of the low nitrogen utilization efficiency (NUE) and high enteric methane $\left(\mathrm{CH}_{4}\right)$ emissions of beef cattle remain the primary concerns in the development of ruminant feeding systems [1]. A low NUE could contribute more ammonia emissions to the air and more manure $\mathrm{N}$ outputs to the soil [2], which could damage air quality [3] and lead to soil nitrification and acidification [2]. The enteric $\mathrm{CH}_{4}$ emissions from ruminants not only represent a loss of diet energy [4] but could also contribute to global warming [5]. The development of a diet that can improve the NUE and reduce enteric $\mathrm{CH}_{4}$ emissions is in demand and would be beneficial to both animal husbandry and in facing global environmental challenges [6,7].

Grass occupies an important role in the ruminant feeding system as it represents a low-cost and abundant source of dry matter (DM). However, grass only is not capable of sustaining the required levels of animal production due to its low feeding value [8]. Hence, the interest in supplementing legumes into a grass-based diet because they are rich in protein and energy [9]. Previous studies in sheep have shown that the intake of organic matter $(\mathrm{OM})$ and crude protein $(\mathrm{CP})$, as well as ruminal ammonia nitrogen $(\mathrm{N})$ concentrations increased with a 3:1 grass/legume mixture diet as compared to a diet of only grass [10]; the total tract digestibility of $\mathrm{CP}$ and digestible $\mathrm{CP}$ was significantly higher in a 1:1 alfalfa/oat mixture diet than oat only hay diet [11]. Moreover, alfalfa $(78 \%)$ and grass $(22 \%)$ pastures could reduce energy loss through $\mathrm{CH}_{4}$ emissions of cows as compared to grass-only pastures [12]. However, these studies focused on diets where supplementation of legumes was the only factor considered. Few studies explained the effects of diets with different levels of legumes on feed intake, digestibility, and $\mathrm{CH}_{4}$ emissions. In another study, the inclusion of $30 \%$ common vetch hay $(\mathrm{CVH})$ was more optimal in reducing $\mathrm{CH}_{4}$ emissions than $0 \%, 10 \%$, and $20 \% \mathrm{CVH}$ diets but significantly depressed digestibility as compared to a $20 \% \mathrm{CVH}$ diet [13]. Recently, Kobayashi et al. [14,15] concluded that $8 \%$ to $14 \%$ alfalfa hay ( $\mathrm{AH}$ ) in the warm season and $8 \%$ to $21 \%$ in the cool season were optimal when considering body weight gain (BWG), metabolizable energy (ME) intake, and increased economic benefits of growing beef cattle on a corn- and straw-based diet.

Alfalfa (Medicago sativa L.) is the mostly widely planted perennial legume crop in the world and has been studied for many years [12,14]. Common vetch (Vicia sativa L.), a multipurpose annual cereal legume for livestock feed [16], not only plays an important role in dryland mixed farming systems [16] for grazing [17] or cutting for hay [18] but also meets the structural forage deficit in winter, which is linked to the seasonality of other feed sources [9]. Previous studies have shown that CP, digestible OM intake, and in vitro OM digestibility are significantly higher with the oat and common vetch mixture diet than with the oat-only diet for cattle [18], and the growth performance of animals is significantly higher with common vetch supplementation than without [19]. However, until now, there has been no available information on whether common vetch could substitute alfalfa in the ruminant feeding system or whether optimal proportions of common vetch could replace alfalfa. Therefore, the objective 
of this study was to investigate how CVH versus $\mathrm{AH}$ affects BWG, N metabolism (i.e., $\mathrm{N}$ digestibility, ruminal ammonia- $\mathrm{N}$, and blood urea $\mathrm{N}$ (BUN) concentrations), and $\mathrm{CH}_{4}$ emissions associated with ruminal fermentation parameters using two different proportions (20\% (20) and 40\% (40) of the total DM allowance) for growing crossbred Simmental cattle in dryland environments at similar CP and predicted ME levels.

\section{Materials and Methods}

The Animal Ethics Committee of Gansu Province, China, approved the experimental protocols (file No. 2010-1 and 2010-2). This study was conducted in Linze Grassland Agriculture Trial Station, Lanzhou University, Zhangye City, Gansu Province, China (latitude $39.24^{\circ} \mathrm{N}$, longnitude $00.06^{\circ} \mathrm{E}$, $1390 \mathrm{~m}$ a.s.1.), which is characterized as a typical temperature continental climate because its average annual precipitation is $121.5 \mathrm{~mm}$ and annual average temperature is $7.7^{\circ} \mathrm{C}$. In this study, the $\mathrm{AH}$ was second cut, and common vetch (Vicia sativa L.cv. Lanjian No. 3) was harvested at the flowering stage and restored as common vetch hay $(\mathrm{CVH})$. Oat hay $(\mathrm{OH} ;$ Avena sativa L.) was purchased from a forage company (Sanbao Agricultural Company, Zhangye, Gansu, China). The ingredients for the concentrate (maize, soybean meal, and wheat bran) were acquired from a local source. The chemical composition of the forage and ingredients of the concentrate are shown in Table 1.

Table 1. Chemical composition of alfalfa hay, oat hay, common vetch hay, and ingredients of the concentrate used in the experimental diets.

\begin{tabular}{ccccccc}
\hline Item & $\begin{array}{c}\text { Alfalfa } \\
\text { Hay }\end{array}$ & $\begin{array}{c}\text { Oat } \\
\text { Hay }\end{array}$ & $\begin{array}{c}\text { Common } \\
\text { Vetch Hay }\end{array}$ & $\begin{array}{c}\text { Soybean } \\
\text { Meal }\end{array}$ & $\begin{array}{c}\text { Wheat } \\
\text { Bran }\end{array}$ & Maize \\
\hline $\mathrm{OM}, \mathrm{g} / \mathrm{kg} \mathrm{DM}$ & 905 & 942 & 918 & 935 & 931 & 983 \\
$\mathrm{CP}, \mathrm{g} / \mathrm{kg} \mathrm{DM}$ & 168 & 60 & 177 & 465 & 182 & 83 \\
$\mathrm{NDF}, \mathrm{g} / \mathrm{kg} \mathrm{DM}$ & 458 & 559 & 413 & 166 & 454 & 100 \\
$\mathrm{ADF}, \mathrm{g} / \mathrm{kg} \mathrm{DM}$ & 347 & 407 & 302 & 102 & 186 & 20 \\
Ether extract, g/kg DM & 22 & 18 & 23 & 26 & 55 & 44 \\
GE, MJ/kg DM & 17.9 & 16.8 & 17.7 & 19.6 & 19.4 & 18.5 \\
$\mathrm{MEC}_{\text {\&, MJ/kg DM }}$ & 8.7 & 9.0 & 9.5 & 13.0 & 10.9 & 13.4 \\
$\mathrm{MPC}^{\text {II }}$, g/kg DM & 62 & 68 & 71 & 87 & 73 & 90 \\
\hline
\end{tabular}

${ }^{+} \mathrm{OM}$, organic matter; $\mathrm{CP}$, crude protein; NDF, neutral detergent fiber; $\mathrm{ADF}$, acid detergent fiber; GE, gross energy; MEC, metabolizable energy concentration; MPC, metabolizable protein concentration; §, II They were calculated by the Agricultural and Food Research Council (1993) and the Chinese Feeding Standard for Beef Cattle (2004), see details in Methods and Materials.

\subsection{Animals, Treatments, and Diets}

The Animal Ethics Committee of Gansu Province, China, approved the experimental protocols. This experiment involved 16 crossbred male Simmental cattle (Simmental $\times$ local cattle) with initial body weights (BWs) of $216 \pm 24.4 \mathrm{~kg}$ (mean \pm standard deviation, 10 months of age) at the start of the experimental period. The experiment used a randomized block experimental design with a $2 \times 2$ factorial arrangement of diets. All 16 cattle were allocated to one of the 4 treatments. The forage to concentrate ratio was fixed (60:40, DM basis) for all diets. Diet treatments used two kinds of legumes (AH and $\mathrm{CVH}$ ) and two different $\mathrm{OH}$-to-AH/CVH ratios in the diet (40:20 or 20:40, DM basis), indicated as follows: $20 \% \mathrm{CVH}$ and $40 \% \mathrm{OH}$ (CVH20), $40 \% \mathrm{CVH}$ and $20 \% \mathrm{OH}(\mathrm{CVH} 40), 20 \% \mathrm{AH}$ and $40 \% \mathrm{OH}$ (AH20), and $40 \% \mathrm{AH}$ and $20 \% \mathrm{OH}$ (AH40). This experiment consisted of 2 feeding periods. Each period consisted of a 14 day diet adaptation in the cowshed and 32 day data collection period in the chambers.

The target BWG for each cattle was set at $1.5 \mathrm{~kg} / \mathrm{d}$. All experimental diets were formulated to provide sufficient ME and metabolizable protein (MP) to meet the target BWG for cattle according to the published estimation equations and values of the Agricultural and Food Research Council [20] and BW of cattle (measured every 8 days). The diet composition required to fulfill the ME and MP requirements was calculated based on the tabulated values of digestible energy and ruminal $\mathrm{CP}$ degradation parameters for $\mathrm{OH}, \mathrm{AH}$, and the concentrate ingredients established by the Chinese 
Feeding Standard for Beef Cattle [21]. The digestibility of ruminal CP and energy and ruminal degradation parameters for CVH were taken from Larbi et al. [16]. The CP, ME, and MP levels of all diets are shown in Table 2. Throughout this experimental period of 8 weeks, all cattle were given free access to water and $10 \mathrm{~g} /$ day of mineral mixture containing (minimum values in $\mathrm{mg}$ ) manganese, 720; copper, 30; biotin, 0.05; folic acid, 0.4; vitamin $B_{1}$, 50; vitamin $B_{2}$, 2.5; vitamin $B_{6}$, 0.5; and vitamin $B_{12}$, 0.1 . The daily mixed forage was divided into two equal parts and offered as separate meals twice a day (08:00 and 19:00). The mixed concentrate was fed once a day (14:00).

Table 2. Composition of the feed ingredients and the target metabolizable energy concentration and metabolizable protein concentration of all diets.

\begin{tabular}{|c|c|c|c|c|}
\hline \multirow{2}{*}{ Feed Formula } & \multicolumn{4}{|c|}{ Experimental Diet $^{\dagger}$} \\
\hline & CVH20 & CVH40 & AH20 & AH40 \\
\hline \multicolumn{5}{|l|}{ Forage } \\
\hline Leguminous forage (g/kg DM) & 200 & 400 & 200 & 400 \\
\hline Oat hay (g/kg DM) & 400 & 200 & 400 & 200 \\
\hline \multicolumn{5}{|l|}{ Concentrate } \\
\hline Maize (g/kg DM) & 30 & 80 & 48 & 120 \\
\hline Soybean meal (g/kg DM) & 92 & 25 & 107 & 56 \\
\hline Wheat bran (g/kg DM) & 278 & 295 & 245 & 224 \\
\hline \multicolumn{5}{|l|}{ Nutrient value $\ddagger$} \\
\hline $\mathrm{CP}(\mathrm{g} / \mathrm{kg} \mathrm{DM})$ & 156.3 & 156.4 & 156.4 & 156.4 \\
\hline $\mathrm{MEC}^{\S}(\mathrm{MJ} / \mathrm{kg} \mathrm{DM})$ & 10.05 & 10.05 & 10.05 & 10.05 \\
\hline $\mathrm{MPC}^{\mathbb{I}}(\mathrm{g} / \mathrm{kg} \mathrm{DM})$ & 102.9 & 94.6 & 106.1 & 101.4 \\
\hline
\end{tabular}

${ }^{\dagger}$ CVH20, $20 \%$ common vetch $+40 \%$ oat hay; $\mathrm{CVH} 40,40 \%$ common vetch $+20 \%$ oat hay; $\mathrm{AH} 20,20 \%$ alfalfa + $40 \%$ oat hay; $\mathrm{AH} 40,40 \%$ alfalfa $+20 \%$ oat hay. $¥ \mathrm{CP}$, crude protein, MEC, metabolizable energy concentration, MPC, metabolizable protein concentration. \$, II These values were calculated by the Agricultural and Food Research Council (1993) and the Chinese Feeding Standard for Beef Cattle (2004); see details in Methods and Materials.

\subsection{Chamber Description}

The four indirect open-respiration calorimeter chambers used in the present study were equipped with a computer-controlled air-handling system with air conditioning units set to a temperature of $18 \pm 1{ }^{\circ} \mathrm{C}$ and relative humidity of $60 \% \pm 10 \%$. The calorimeter chambers were built with double Perspex walls fitted in aluminum frames [22], with a total volume of approximately $18 \mathrm{~m}^{3}(4.2 \mathrm{~m} \mathrm{long}$, $1.95 \mathrm{~m}$ wide, and $2.2 \mathrm{~m}$ high). Each chamber was equipped with a gas flow meter (GFM57, Aalborg, Orangeburg, New York, NY, USA) at the outflow site for recording the total airflow and an engine to ensure a slight negative pressure within the chamber. All chambers were ventilated by suction pumps with a flow rate of 45 to $50 \mathrm{~m}^{3} / \mathrm{h}$. The exhaust air was removed for volume, temperature, and humidity measurement and analysis in the bottom, middle, and upper areas, inside each chamber. The concentrations of $\mathrm{CO}_{2}, \mathrm{CH}_{4}$, and $\mathrm{O}_{2}$ in the air moving into and out of each chamber were measured every $16 \mathrm{~min}$ (the interval for each chamber) using a multigas analyzer (VA-3000, Horiba Ltd., Tokyo, Japan) in a general control room. The analyzer was calibrated using standard gases $\left(\mathrm{O}_{2}-\mathrm{free}_{2} \mathrm{~N}_{2}\right.$ and a known quantity of $\mathrm{CH}_{4}, \mathrm{CO}_{2}$ and $\mathrm{O}_{2}$, Dalian Special Gases Co., Ltd., Liaoning, China) at the beginning of the gas exchange collection period in each experiment. The determined concentrations were in an absolute range of $0-500 \mu \mathrm{L} / \mathrm{L}$ for $\mathrm{CH}_{4}, 0-2000 \mu \mathrm{L} / \mathrm{L}$ for $\mathrm{CO}_{2}$, and $0 \%-25 \%(v / v)$ for $\mathrm{O}_{2}$ (with linearity within this range). The recovery rate of $\mathrm{CH}_{4}$ was determined by comparing the $\mathrm{CH}_{4}$ release into the chamber with a given concentration as well as the $\mathrm{CH}_{4}$ concentration at the outlet. The gas recovery rate was approximately $100 \% \pm 2 \%$ for all chambers, as highlighted recently by Gerrits et al. [23]. Each chamber was designed with a dedicated door, which was located next to the animal trough. The staff only opened the door to feed the animal immediately after the completion of each data collection in the chamber during the 3 day gas exchange data collection period. This minimized the effects of feeding activity (less than $1 \mathrm{~min}$ ) on the gas concentrations inside. The $\mathrm{CH}_{4}$ emissions were 
expressed as the average $\mathrm{CH}_{4}$ emissions (g/day) from 3-day measurements divided by BWG, which was calculated from the BW change between moving in and moving out the chamber.

\subsection{Energy Balance}

ME intake (MEI) was calculated as the difference between GEI, excreted fecal energy (FE), and the sum of $\mathrm{UE}$ and $\mathrm{CH}_{4}$ energy $\left(\mathrm{CH}_{4}\right.$-E) output. Retained energy (RE) was calculated using the equation MEI - heat production (HP). $\mathrm{CH}_{4}$-E was calculated from $\mathrm{CH}_{4}$ emissions (L/day) and the conversion coefficient $\left(39.54 \mathrm{~kJ} / \mathrm{L}\right.$; [24]). The $\mathrm{CH}_{4}$ emissions was converted to grams from the $\mathrm{CH}_{4}$ emissions (L/day) using the conversion coefficient $(0.716 \mathrm{~g} / \mathrm{L},[24]) . \mathrm{HP}(\mathrm{kJ} /$ day) was calculated with the following equation [24]:

$$
\begin{gathered}
\mathrm{HP}(\mathrm{kJ} / \text { day })=16.18 \times \mathrm{O}_{2} \text { consumption }(\mathrm{L} / \text { day })+5.02 \times \mathrm{CO}_{2} \text { production }(\mathrm{L} / \text { day }) \\
\left.\quad-2.17 \times \mathrm{CH}_{4} \text { production }(\mathrm{L} / \text { day })-5.99 \times \mathrm{N} \text { excretion (urinary } \mathrm{N}, \mathrm{g} / \text { day }\right)
\end{gathered}
$$

\subsection{Sample Collection and Procedures}

The amount of offered forage and concentrate and all leftovers was weighed daily throughout the experimental period to calculate the daily DM intake (DMI) for individual cattle. On day 15 of the experimental period, after the 14 day acclimation period for target feeds, one cattle was randomly selected from each diet group and moved to one of the four chambers for 8 days. On day 22, these cattle were moved to the individual pens in the cowshed, and another 4 cattle, randomly selected from the remaining cattle of the four diet groups, entered the chambers and left on day 30 . This process continued until day 46 for the first feeding period, when all 16 cattle had completed 8 days of measurement. These acclimation and chamber measurements for metabolism and gas exchange were repeated for another 46 days with the 16 cattle randomly allocated to the four diets. The BWs of all cattle were measured in the morning with an empty stomach to calculate $\mathrm{CH}_{4}$ emissions, energy, and $\mathrm{N}$ balance based on the metabolic BW when exchanging cattle between the chambers and the cowshed. The BWG (kg/day) was calculated by the difference of the BW at the start and end time of each feeding period. During the 8 days of measurements in the chamber, the cattle were kept for acclimation for the first 2 days. We collected the digestibility data over the following 3 days and gas exchange data $\left(\mathrm{O}_{2}\right.$ consumption, $\mathrm{CH}_{4}$, and $\mathrm{CO}_{2}$ emission) over the remaining 3 days. During the digestibility data collection period, the total weight of the daily excreted feces and urine was recorded. Feces, which were excreted onto a plastic mat placed under the cattle, were collected right after excretion with a shovel and placed into a plastic container (around 15 times a day but varied according to individuals) and weighed, mixed, and sampled once per day. A total of $10 \%$ of each feces sample was stored at $-20{ }^{\circ} \mathrm{C}$ for later chemical analysis. All urine was collected once a day through a handmade urine bag into a bucket containing $200 \mathrm{~mL} \mathrm{10 \%}(v / v) \mathrm{H}_{2} \mathrm{SO}_{4}$ to reduce ammonia loss. Acidified urine was checked for $\mathrm{pH}$ with a portable $\mathrm{pH}$ instrument (PHBJ-260, Shanghai INESA Scientific Instrument Co., Ltd., Shanghai, China). A total of $20 \%$ of the daily urine was removed with a $500 \mathrm{~mL}$ cylinder (deviation \pm $5 \mathrm{~mL}$ ) and stored at $-20{ }^{\circ} \mathrm{C}$ for chemical analysis.

Rumen fluid samples were taken from each cattle $4 \mathrm{~h}$ post forage supply every morning using stomach tubing on the last 2 days of each feeding period after these cattle were moved to the cowshed. The collected samples were immediately measured for $\mathrm{pH}$ using a portable $\mathrm{pH}$ meter (PHBJ-260, Shanghai INESA Scientific Instrument Co., Ltd., Shanghai, China), strained through two layers of muslin (mesh size $1 \mathrm{~mm}^{2}$ ) and stored at $-20{ }^{\circ} \mathrm{C}$ for volatile fatty acid (VFA) analysis. An additional $1 \mathrm{~mL}$ of strained rumen fluid was deproteinated by adding $0.2 \mathrm{~mL}$ metaphosphoric acid (215 g/L) and $0.1 \mathrm{~mL}$ internal standard (Crotonic acid), and the VFA concentrations were determined by a gas chromatograph (Trace1300, Thermo Ltd., Rodano Milan, Italy) fitted with a polar capillary column. The plasma urea $\mathrm{N}$ concentration was assumed to be equivalent to the BUN concentration in the serum, since urea diffuses freely into and out of blood cells [25]. 


\subsection{Chemical Analysis}

After the chamber measurement, the stored feces samples were thawed at room temperature for $12 \mathrm{~h}$, and the feces samples from each cattle over the three days were then mixed. A portion of the thawed feces sample was used for the $\mathrm{N}$ measurement according to the Association of Official Analytical Chemists methods, method 976.05 [26]. The CP concentration was calculated by multiplying the $\mathrm{N}$ concentration by 6.25 . The remaining samples were oven dried at $65{ }^{\circ} \mathrm{C}$ for $48 \mathrm{~h}$ and then ground to pass through a $1 \mathrm{~mm}$ screen. A portion of each dried sample, mixed forage, and concentrate samples were used to measure ash by combustion using a muffle furnace at $550{ }^{\circ} \mathrm{C}$ for $10 \mathrm{~h}$ (method $942.05[26])$. The organic matter (OM) content (g/kg DM) was calculated by 1000 ash content $(\mathrm{g} / \mathrm{kg} \mathrm{DM})$. Another portion of each dried sample was finely ground to measure gross energy (GE), neutral detergent fibers (NDFs), and acid detergent fibers (ADFs). The GE of the samples was determined with an automatic isoperibol calorimeter (6400, PARR Instrument Company, Moline, IL, USA). The NDF and ADF concentrations were analyzed sequentially in an ANKOM 2000 fiber analyzer (ANKOM Technology, Fairport, NY, USA) following the protocol described by Van Soest [27]. The ash was included to facilitate the NDF and ADF analysis of all the forage, concentrate, and feces samples. The $\alpha$-amylase for NDF analysis was used only for the concentrate samples. The urine samples from each cattle over the three days were also thawed at room temperature for $12 \mathrm{~h}$ and then mixed before determining their urinary energy (UE) by using an automatic isoperibol calorimeter (see above), and $\mathrm{N}$ was determined using Kjeldahl procedure described previously by the Association of Official Analytical Chemists [26]. For the UE measurement, $4 \mathrm{~mL}$ fully mixed urine was taken and absorbed by a filter paper of a known weight, and then the total energy of the filter paper with a urine sample was measured by an automatic isoperibol calorimeter after it became dry at room temperature. There were another 5 samples using the same filter paper (known weight) to be measured for energy content $(\mathrm{MJ} / \mathrm{kg})$, which was used to calculate the UE. The measurements of CP, NDF, and GE of the forage and concentrate of the diets also followed the above methods and instruments. The ether extract of the forage and concentrate was analyzed using an ANKOM XT15 Extractor (ANKOM Technology, Fairport, NY, USA).

\subsection{Statistical Analysis}

A one-way analysis of variance (ANOVA) and generalized linear model analysis were used to investigate the effects of legume species (LS), legume proportion (LP), and their interactions $(\mathrm{LS} \times \mathrm{LP})$ on DMI, BWG, nutrient digestibility, energy balance, $\mathrm{N}$ metabolism, and energy/N utilization efficiency. Differences among the means were considered to be significant at a $p \leq 0.05$ on the basis of Tukey's test, unless otherwise stated. The statistical program used in the current study was IBM SPSS Statistics for Windows, version 19.0 (IBM Corp., Armonk, NY, USA).

\section{Results}

\subsection{Feed Intake, Apparent Nutrient Digestibility, and BWG}

LS significantly influenced the forage DMI and total DMI $(p<0.05$, Table 3$)$. In detail, the forage DMI and total DMI of cattle were significantly higher when fed on a CVH40 diet than on AH20 and AH40 diets $(p<0.05$, Figure 1a). However, no significant differences were found in the concentrate DMI under LS ( $p>0.05$, Table 3). In addition, there were no significant differences in the forage DMI, concentrate DMI, and total DMI of cattle under LP ( $p>0.05$, Table 3, Figure 1a). 
Table 3. A general linear model analysis of legume species (LS), legume proportion (LP), and their interaction effect on feed intake, digestibility, growth performance, and $\mathrm{CH}_{4}$ emissions $(\mathrm{n}=8)$.

\begin{tabular}{|c|c|c|c|}
\hline Item $^{+}$ & LS $\ddagger$ & LP $\ddagger$ & $\mathbf{L S} \times \mathbf{L P} \ddagger$ \\
\hline \multicolumn{4}{|l|}{ Dry matter intake (DMI) } \\
\hline Forage DMI (g/kg BW $0.75 /$ day) & $5.783^{*}$ & 0.932 & 0.498 \\
\hline Concentrate DMI (g/kg BW ${ }^{0.75} /$ day) & 1.108 & 1.189 & 0.001 \\
\hline Total DMI (g/kg BW'0.75/day) & $5.207^{*}$ & 0.109 & 0.598 \\
\hline \multicolumn{4}{|l|}{ Digestibility } \\
\hline DM digestibility (\%) & 0.215 & $5.671^{*}$ & 1.303 \\
\hline OM digestibility (\%) & 0.306 & $6.744^{*}$ & 1.582 \\
\hline NDF digestibility (\%) & 1.177 & $18.476^{* * *}$ & 0.001 \\
\hline Apparent $\mathrm{N}$ digestibility (\%) & $5.515^{*}$ & $5.949^{*}$ & 0.265 \\
\hline \multicolumn{4}{|l|}{ Growth performance } \\
\hline BWG (kg/day) & 0.205 & 0.403 & 1.389 \\
\hline FCR (kg BWG/kg DMI) & 0.077 & 2.515 & $5.796^{*}$ \\
\hline \multicolumn{4}{|l|}{$\mathrm{CH}_{4}$ emissions } \\
\hline $\mathrm{CH}_{4}$ emissions (g/kg BW $\left.{ }^{0.75} / 24 \mathrm{~h}\right)$ & $5.907^{*}$ & $7.056^{*}$ & 0.815 \\
\hline $\mathrm{CH}_{4}$ emissions (g/kg DMI/24 h) & 1.698 & $5.604^{*}$ & 0.000 \\
\hline
\end{tabular}

${ }^{\dagger}$ DMI, dry matter intake; DM, dry matter; OM, organic matter; NDF, neutral detergent fiber; BWG, body weight gain; FCR, feed conversion ratio (ratio of BWG divided by the total DMI). ${ }^{\ddagger}$ values are the F value, ${ }^{*} p<0.05$, and $p<0.001$.


Figure 1. The dry matter intake (DMI) (a), digestibility (b), body weight gain (BWG) (c) and feed conversion rate (d) of cattle among the four diet groups. Values are presented as the mean \pm standard deviation (SD). Uppercase letters only represent the difference among the four diet groups.

LP significantly affected the nutrient digestibility of cattle, including the digestibility of DM, OM, NDF, and apparent N ( $p<0.05$, Table 3). Specifically, the digestibility of the DM, OM, and NDF of cattle when fed on an AH40 diet were significantly lower than those on an AH20 diet $(p<0.05$, Figure 1b). 
In the CVH diet groups, only NDF digestibility was significantly lower in the CVH40 diet group than in the CVH20 diet group ( $p<0.05$, Figure 1b).

Both LS and LP did not significantly influence BWG and the feed conversion rate (FCR) of cattle $(p>0.05$, Table 3), but the interaction between LS and LP had a significant effect on the FCR of cattle $(p<0.05$, Table 3$)$. In detail, the AH40 diet group had a significantly lower FCR than that in the AH20 diet group $(p<0.05$, Figure 1d), whereas there was no difference between the CVH20 and CVH40 diet groups $(p>0.05$, Figure $1 \mathrm{~d})$.

\subsection{Enteric $\mathrm{CH}_{4}$ Emission, Energy Balance, and Energy Utilization Efficiency}

$\mathrm{CH}_{4}$ emissions, expressed on a milligram scale every 15 min per kilogram of metabolic BW and on a gram scale per kilogram DMI over $24 \mathrm{~h}$ post feeding, are shown in Figure 2a,b, respectively. There were intermittent peaks throughout the day and it was apparent that the peaks occurred a short time after feed supply. Moreover, the peaks of $\mathrm{CH}_{4}$ emissions ( $\mathrm{mg} / \mathrm{kg} \mathrm{BW} \mathrm{B}^{0.75}$ or $\left.\mathrm{g} / \mathrm{kg} \mathrm{DMI}\right)$ were relatively higher after the concentrate supply than after the forage supply (Figure 2a,b).

Both LS and LP could significantly affect $\mathrm{CH}_{4}$ emissions $\left(\mathrm{g} / \mathrm{kg} \mathrm{BW} \mathrm{B}^{0.75}\right)$ over $24 \mathrm{~h}(p<0.05$, Table 3$)$. Individually, the $\mathrm{CVH}$ diet groups had lower accumulated $\mathrm{CH}_{4}$ emissions $\left(\mathrm{g} / \mathrm{kg} \mathrm{BW}{ }^{0.75}\right)$ than the $\mathrm{AH}$ diet groups (Figure 2c), and the $\mathrm{CVH} 40$ and $\mathrm{AH} 40$ diet groups had relatively lower accumulated $\mathrm{CH}_{4}$ emissions ( $\left(\mathrm{g} / \mathrm{kg} \mathrm{BW}^{0.75}\right)$ than the $\mathrm{CVH} 20$ and $\mathrm{AH} 20$ diet groups (Figure $2 \mathrm{c}$ ). In addition, the accumulated $\mathrm{CH}_{4}$ emissions $\left(\mathrm{g} / \mathrm{kg} \mathrm{BW}{ }^{0.75}\right.$ ) were significantly lower in the CVH40 diet group than in the AH20 diet group ( $p<0.05$, Figure 2c). For $\mathrm{CH}_{4}$ emissions per kilogram DMI in a $24 \mathrm{~h}$ period, $\mathrm{LP}$ had a significant effect $(p<0.05$, Table 3$)$. In summary, the CVH40 diet group had significantly lower accumulated $\mathrm{CH}_{4}$ emission $(\mathrm{g} / \mathrm{kg}$ DMI) than the AH20 diet group $(p<0.05$, Figure $2 \mathrm{c})$.

Accumulated $\mathrm{CH}_{4}$ emissions per metabolic $\mathrm{BW}$ and per kilogram DMI after forage and concentrate supply in a $24 \mathrm{~h}$ period are shown in Figure $2 \mathrm{~d}-\mathrm{f}$. Accumulated $\mathrm{CH}_{4}$ emissions $\left(\mathrm{g} / \mathrm{kg} \mathrm{BW}^{0.75}\right)$ after forage supply in the morning were significantly lower in the CVH40 and AH40 diet groups than in the CVH20 and AH20 diet groups, respectively ( $p<0.05$, Figure 2d), and the CVH40 diet group had a significantly lower value than the AH20 diet group, regardless of forage supply in the morning or night $(p<0.05$, Figure $2 \mathrm{~d}, \mathrm{f})$. There was a similar trend between the accumulated $\mathrm{CH}_{4}$ emissions in grams per kilogram of metabolic BW and grams per kilogram DMI (Figure 2d). There were no significant differences in accumulated $\mathrm{CH}_{4}$ emissions ( $\mathrm{g} / \mathrm{kg} \mathrm{DMI}$ ) among the four diet groups $(p>0.05$, Figure 2e) after concentrate supply, whereas the accumulated $\mathrm{CH}_{4}$ emissions $\left(\mathrm{g} / \mathrm{kg} \mathrm{BW}^{0.75}\right)$ were significantly higher in the CVH20 diet group than in the CVH40 diet group after concentrate supply $(p<0.05$, Figure 2e).

LS only significantly affected MEI and HP ( $p<0.05$, Table 4$)$. In particular, the CVH diet groups had higher MEI and HP than the AH diet groups (Figure 3a,e). Within the legume diet groups, LP only significantly influenced FE output $(p<0.05$, Table 4$)$. The CVH40 and AH40 diet groups had higher FE output than the CVH20 and AH20 diet groups (Figure 3d), whereas FE only significantly differed between the AH20 and AH40 diet groups ( $p<0.05$, Figure 3d). For energy utilization efficiency, LP only significantly influenced the ratio of FE to GEI $(p<0.05$, Table 4$)$. In detail, this ratio was significantly higher in the AH40 diet group than in the CVH20 and AH20 diet groups ( $p<0.05$, Figure $3 \mathrm{~d})$. 

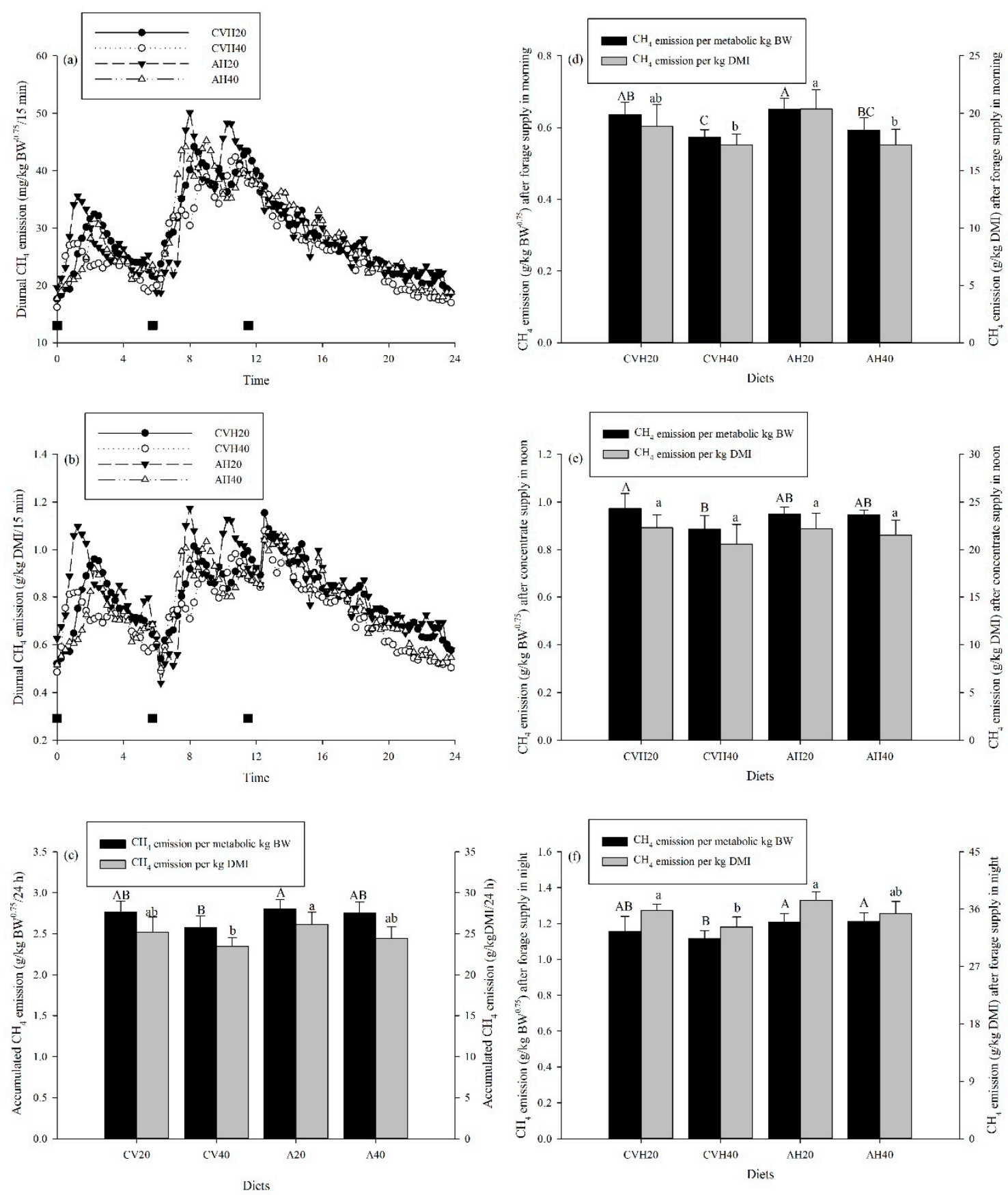

Figure 2. Diurnal $\mathrm{CH}_{4}$ emissions (a) and (b), accumulated $\mathrm{CH}_{4}$ emissions (c) after forage supply in the morning (d), after the concentrate supply in noon (e) and after forage supply in the night (f) for cattle among the four diet groups. Values are presented as the mean \pm standard deviation (SD). Uppercase letters represent the differences among the four diet groups per kilogram of metabolic body weight, and lowercase letters represent the difference among the four diet groups per kilogram dry matter intake (DMI). 

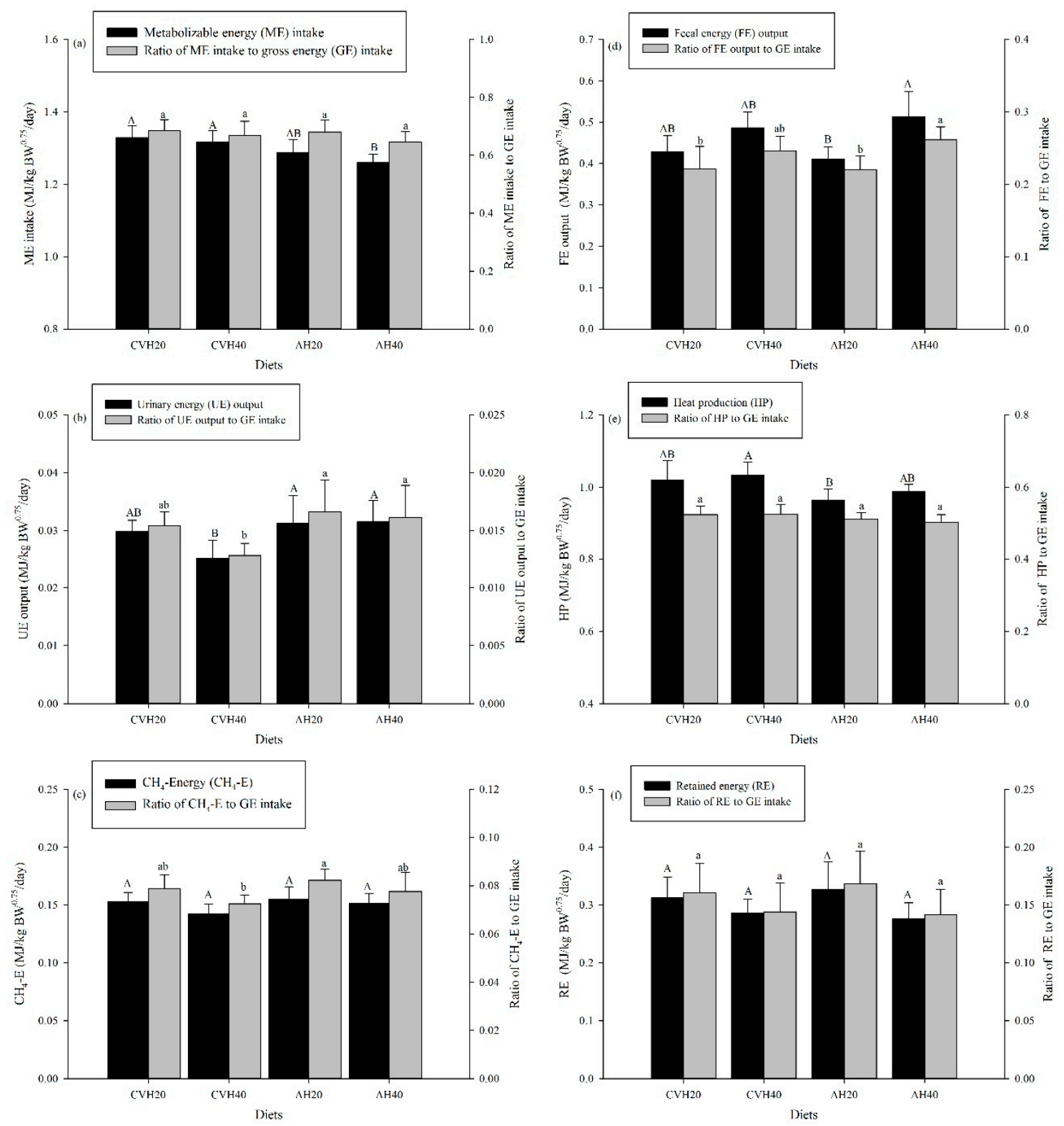

Figure 3. The energy balance and utilization efficiency of cattle among the four diet groups. Values are presented as the mean \pm standard deviation (SD). Uppercase letters represent the differences among the four diet groups in energy balance, and lowercase letters represent the differences among the four diet groups in energy utilization. (a-f) represent ME intake, UE output, $\mathrm{CH}_{4}$-E, $\mathrm{FE}$ output, $\mathrm{HP}$, and RE, respectively, as well as their proportion of GE intake.

Table 4. A general linear model analysis of legume species (LS), legume proportion (LP) and their interaction effects on energy balance/nitrogen balance and energy/nitrogen utilization efficiency $(n=8)$.

\begin{tabular}{cccc}
\hline Item $^{\dagger}$ & LS $\ddagger$ & LP $\ddagger$ & LS $\times$ LP $\ddagger$ \\
\hline Energy balance & & & \\
GE intake $\left(\mathrm{MJ} / \mathrm{kg} \mathrm{BW}^{0.75} /\right.$ day) & 1.302 & 2.783 & 0.126 \\
$\mathrm{ME}$ intake $\left(\mathrm{MJ} / \mathrm{kg} \mathrm{BW}^{0.75} /\right.$ day) & $6.749^{*}$ & 1.132 & 0.127 \\
$\mathrm{FE}$ output $\left(\mathrm{MJ} / \mathrm{kg} \mathrm{BW}^{0.75} /\right.$ day) & 0.042 & $13.7399^{* *}$ & 1.054 \\
$\mathrm{UE} \mathrm{output}\left(\mathrm{MJ} / \mathrm{kg} \mathrm{BW}^{0.75} /\right.$ day) & 4.675 & 1.584 & 1.992 \\
$\mathrm{CH}_{4}-\mathrm{E}\left(\mathrm{MJ} / \mathrm{kg} \mathrm{BW}^{0.75} /\right.$ day) & 1.604 & 2.225 & 0.684 \\
$\mathrm{HP}\left(\mathrm{MJ} / \mathrm{kg} \mathrm{BW}^{0.75} /\right.$ day) & $6.208^{* *}$ & 1.198 & 0.170 \\
$\mathrm{RE}\left(\mathrm{MJ} / \mathrm{kg} \mathrm{BW}^{0.75} /\right.$ day) & 0.012 & 4.758 & 0.469 \\
\hline
\end{tabular}


Table 4. Cont.

\begin{tabular}{|c|c|c|c|}
\hline Item $^{\dagger}$ & LS $\ddagger$ & $\mathbf{L P} \ddagger$ & $\mathbf{L S} \times \mathbf{L P} \ddagger$ \\
\hline \multicolumn{4}{|l|}{ Energy utilization efficiency } \\
\hline Ratio of ME intake to GE intake (MJ/MJ) & 0.436 & 1.589 & 0.224 \\
\hline Ratio of FE output to GE intake (MJ/MJ) & 0.392 & $8.630^{*}$ & 0.504 \\
\hline Ratio of UE output to GE intake (MJ/MJ) & 4.647 & 2.254 & 1.025 \\
\hline Ratio of HP to GE intake (MJ/MJ) & 2.189 & 0.148 & 0.171 \\
\hline Ratio of $\mathrm{CH}_{4}$-E to GE intake (MJ/MJ) & 2.332 & 3.644 & 0.066 \\
\hline Ratio of RE to GE intake (MJ/MJ) & 0.051 & 2.993 & 0.178 \\
\hline \multicolumn{4}{|l|}{ Nitrogen balance } \\
\hline $\mathrm{N}$ intake (g/kg BW $\mathrm{BW}^{0.75} /$ day) & 2.956 & 1.317 & 0.168 \\
\hline FN output (g/kg BW ${ }^{0.75} /$ day) & $8.792^{*}$ & $21.653^{* * *}$ & 0.207 \\
\hline UN output (g/kg BW ${ }^{0.75} /$ day) & $9.602^{* *}$ & 0.046 & 0.176 \\
\hline $\mathrm{RN}$ (g/kg BW ${ }^{0.75} /$ day) & $21.681^{* * *}$ & 3.876 & 3.038 \\
\hline \multicolumn{4}{|l|}{ N metabolism } \\
\hline Ruminal ammonia N (mmol/L) & 2.044 & $12.989^{* *}$ & 1.685 \\
\hline Blood urea $\mathrm{N}(\mathrm{mmol} / \mathrm{L})$ & $14.243^{* *}$ & $6.884^{*}$ & 0.970 \\
\hline Urinary ammonia $\mathrm{N}$ (mmol/L) & 0.241 & 1.420 & 0.140 \\
\hline \multicolumn{4}{|l|}{ Nitrogen utilization efficiency } \\
\hline Ratio of FN output to N intake $(\mathrm{g} / \mathrm{g})$ & 3.464 & $12.862^{* *}$ & 0.459 \\
\hline Ratio of UN output to N intake $(\mathrm{g} / \mathrm{g})$ & $16.116^{* *}$ & 0.311 & 0.398 \\
\hline Ratio of $\mathrm{RN}$ to $\mathrm{N}$ intake $(\mathrm{g} / \mathrm{g})$ & $5.992^{*}$ & 4.759 & 1.252 \\
\hline
\end{tabular}

${ }^{\dagger} \mathrm{GE}$, gross energy; $\mathrm{ME}$, metabolizable energy; $\mathrm{FE}$, fecal energy; UE, urinary energy; $\mathrm{CH}_{4}-\mathrm{E}$, methane energy; $\mathrm{HP}$, heat production; RE, retained energy; $\mathrm{N}$ intake, nitrogen intake; FN, fecal N; UN, urinary N; RN, retained N. $¥$ Values are the F value, ${ }^{*} p<0.05,{ }^{* *} p<0.01$, and ${ }^{* * *} p<0.001$.

\subsection{N Balance, N Metabolism, and NUE}

LS did not affect the NI of cattle, but it significantly affected the FN, UN and RN outputs in $\mathrm{N}$ balance $(p<0.05$, Table 4$)$. Although the UN output of the CVH20 and CVH40 diet groups was significantly lower than that in the AH40 diet group ( $p<0.05$, Figure $4 \mathrm{~b})$, the $\mathrm{CVH}$ diet groups had a relatively higher FN output, especially between the CVH40 and AH20 diet groups ( $p<0.05$, Figure $4 c)$. As a consequence, the $\mathrm{RN}$ of cattle in the $\mathrm{CVH} 20$ and $\mathrm{CVH} 40$ diet groups was significantly higher than that in the AH40 diet group ( $p<0.05$, Figure $4 \mathrm{~d}$ ). For the effect of LP on N balance, the CVH40 and AH40 diet groups had relatively higher FE outputs than the CVH20 and AH20 diet groups, but FE output only significantly differed between the AH20 and AH40 diet groups ( $p<0.05$, Table 4 , Figure 4 c).

LP could significantly influence ruminal ammonia-N concentration $(p<0.05$, Table 4$)$, which was significantly lower in the AH40 diet group than in the AH20 and CVH20 diet groups $(p<0.05$, Figure $4 \mathrm{e})$. Both LS and LP significantly affected BUN concentration $(p<0.05$, Table 4$)$, and AH20 had a significantly lower BUN than the AH20, CVH20, and CVH40 diet groups ( $p<0.05$, Figure $4 \mathrm{f})$. No differences were found for the urinary ammonia- $\mathrm{N}$ concentration among the four diet groups $(p>0.05$, Table 4$)$.

LP significantly affected the ratio of FN to NI $(p<0.05$, Table 4). The AH20 diet group had a significantly lower FN to NI than that in the AH40 and CVH40 diet groups ( $p<0.05$, Figure $4 \mathrm{c}$ ). Moreover, LS significantly influenced the ratio of UN to NI $(p<0.05$, Table 4$)$ and the ratio of RN to NI $(p<0.05$, Table 4$)$. The CVH40 diet group had a significantly lower UN:NI than the AH20 and AH40 diet groups ( $p<0.05$, Figure $4 \mathrm{~b}$ ), and the CVH20 diet group had a significantly higher RN:NI than the AH40 diet group $(p<0.05$, Figure 4 d). 



Figure 4. Nitrogen balance and utilization efficiency of cattle among the four diet groups. Values are presented as the mean \pm standard deviation (SD). Uppercase letters represent the differences among the four diet groups in nitrogen balance and lowercase letters represent the differences among the four diet groups in nitrogen utilization. (a) represents $\mathrm{N}$ intake and apparent $\mathrm{N}$ digestibility; (b-d) represent $\mathrm{UN}$ output, FN output, and RN, respectively, as well as their proportion of $\mathrm{N}$ intake; (e) represents ruminal ammonia $\mathrm{N}$ and urinary ammonia $\mathrm{N}$ concentrations; (f) represents blood urea $\mathrm{N}$.

\subsection{Ruminal Fermentation Parameters}

The total VFA and $\mathrm{pH}$ of the ruminal fluid did not significantly differ among the four diet treatments $(p>0.05$, Table 5). However, the molar proportion of acetate was significantly lower in the CVH40 and AH40 diet groups than in the CVH20 and AH20 diet groups, respectively $(p<0.05$, Table 5). Additionally, the molar proportion of acetate was also significantly lower in the CVH diet groups than in the AH diet groups ( $p<0.05$, Table 5). The molar proportions of propionate in the CVH40 and AH40 diet groups were significantly higher than those in the $\mathrm{CVH} 20$ and $\mathrm{AH} 20$ diet groups, respectively 
$(p<0.05$, Table 5). As a consequence, the ratio of acetate to propionate was significantly lower in the CVH40 and AH40 diet groups than in the CVH20 and AH20 diet groups ( $p<0.05$, Table 5$)$.

Table 5. Effects of different diets on the ruminal fermentation parameters in Simmental crossbred cattle.

\begin{tabular}{|c|c|c|c|c|c|c|c|}
\hline \multirow{2}{*}{ Item } & \multicolumn{4}{|c|}{ Experimental Diet $^{+}$} & \multicolumn{3}{|c|}{ Variance Analysis ‡ } \\
\hline & CVH20 & CVH40 & AH20 & AH40 & LS & LP & LS $\times$ LS \\
\hline Total VFA, mmol/L & $75.4 \pm 6.73$ & $72.5 \pm 7.22$ & $77.8 \pm 3.32$ & $75.7 \pm 9.98$ & 0.536 & 0.423 & 0.011 \\
\hline $\mathrm{pH}$ & $6.07 \pm 0.16$ & $6.12 \pm 0.25$ & $6.05 \pm 0.08$ & $6.01 \pm 0.06$ & 0.686 & 0.009 & 0.293 \\
\hline \multicolumn{8}{|l|}{ Molar proportions (mol/100 mol) } \\
\hline Acetate & $72.3 \pm 1.24$ & $70.8 \pm 0.56$ & $73.8 \pm 0.64$ & $72.7 \pm 1.13$ & $11.967^{* *}$ & $6.503^{*}$ & 0.122 \\
\hline Propionate & $14.4 \pm 0.24$ & $15.7 \pm 1.08$ & $13.9 \pm 0.76$ & $15.2 \pm 0.75$ & 1.382 & $10.576^{* *}$ & 0.007 \\
\hline Butyrate & $10.2 \pm 1.11$ & $10.2 \pm 1.44$ & $9.2 \pm 0.72$ & $8.9 \pm 0.46$ & 4.747 & 0.072 & 0.042 \\
\hline Iso-butyrate & $1.1 \pm 0.06$ & $1.2 \pm 0.19$ & $1.1 \pm 0.20$ & $1.1 \pm 0.15$ & 0.173 & 0.640 & 0.539 \\
\hline Valerate & $0.7 \pm 0.12$ & $0.6 \pm 0.08$ & $0.6 \pm 0.18$ & $0.6 \pm 0.05$ & 1.444 & 1.950 & 0.544 \\
\hline Iso-valerate & $1.23 \pm 0.09$ & $1.44 \pm 0.24$ & $1.32 \pm 0.23$ & $1.37 \pm 0.18$ & 0.003 & 1.780 & 0.679 \\
\hline Acetate/propionate ratio & $5.01 \pm 0.11$ & $4.53 \pm 0.30$ & $5.32 \pm 0.30$ & $4.78 \pm 0.31$ & 3.987 & $11.522^{* *}$ & 0.036 \\
\hline
\end{tabular}

${ }^{+}$CVH20, $20 \%$ common vetch $+40 \%$ oat hay; $\mathrm{CVH} 40,40 \%$ common vetch $+20 \%$ oat hay; $\mathrm{AH} 20,20 \%$ alfalfa $+40 \%$ oat hay; AH40, $40 \%$ alfalfa $+20 \%$ oat hay. $¥$ Values are presented as the mean \pm standard deviation (SD); LS, legume species; LP, legume proportion; LS $\times \mathrm{LP}$, interaction between LS and LP. Values are the F value; ${ }^{*} p<0.05 ;{ }^{* *} p<0.01$.

\section{Discussion}

\subsection{Feed Intake, Nutrient Digestibility, and BWG}

In general, feed intake is restricted by the capacity of the rumen [22] and NDF content, which is a measure of cell wall content, and the digestibility of forage $[28,29]$. In this study, the higher forage DMI in the $\mathrm{CVH}$ diet groups than in the AH diet groups ( $p<0.05$, Table 3, Figure 1a) could be attributed to the lower NDF content in CVH (Table 1). This indicates that feeds equal in digestibility but different in NDF content would result in different intakes [22]. The similar DM digestibility (Figure 1b) in CVH20 and $\mathrm{AH} 20$, as well as $\mathrm{CVH} 40$ and $\mathrm{AH} 40$ (Figure 1b), along with the higher DMI in the CVH diet groups, confirm the above deduction.

The digestibility of mixed feed is affected by the feed's chemical composition [22]. For example, forage intake with increasing legume proportions could promote the passage rate of feedstuff in the rumen [12] because legumes have lower fiber content than grass, which reduces the retention time of forage in the rumen [22,30]. In this study, the lower NDF digestibility in diets with higher legume proportions than those in the lower legume proportion diets (Table 3, Figure 1b) confirms the above finding. Compared to grasses, highly lignified cell walls could decrease cell wall digestion in legumes and then decrease OM digestion in the rumen [31]. The lower OM digestibility in higher legume proportion diets as compared to those with lower proportions supports the previous finding (Figure 1b).

\subsection{Enteric $\mathrm{CH}_{4}$ Emission and Ruminal Fermentation}

There is a clear relationship between forage type, concentrate feed or starch intake, OM digestibility, and patterns of ruminal fermentation [4]. In this study, the lower $\mathrm{CH}_{4}$ emissions in the diets with higher proportions of legumes than in those with lower ones, regardless of the per kilogram metabolic BW or per kilogram DMI ( $p<0.05$, Table 3, Figure 2c), indicate that a diet with a higher proportion of legumes could decrease $\mathrm{CH}_{4}$ emissions. This is consistent with the findings of Lee et al. [32], who reported that increasing the percentage of white clover feed with perennial ryegrass could decrease $\mathrm{CH}_{4}$ emissions. This could be attributed to the polyphenolic compounds in legumes, such as condensed tannins, which have been previously shown to be negatively correlated with $\mathrm{CH}_{4}$ emissions [33]. For rumen fermentation, there is a negative relationship between $\mathrm{CH}_{4}$ emissions and propionate formation in the rumen, which could depress the activity of methanogens [4,5]. In this study, the lower ratios of acetate to propionate (Table 5) correspond to lower $\mathrm{CH}_{4}$ emissions after forage supply (Figure 2d) in diet groups with a higher proportion of legumes and this is consistent with the above finding. In addition, 
it has been reported that lipid supplementation could reduce $\mathrm{CH}_{4}$ emissions [34,35]. In this study, legumes have higher concentrations of crude fat (ether extract) than grasses (Table 2), which led to a higher crude fat concentration per unit of DM in the diets with higher proportions of legume than in those with lower proportions. The lower $\mathrm{CH}_{4}$ emissions in the $\mathrm{CVH} 40$ and $\mathrm{AH} 40$ diet groups than in the $\mathrm{CVH} 20$ and $\mathrm{AH} 20$ groups could also be explained in the same way. More importantly, feed intake is the single most important determinant of $\mathrm{CH}_{4}$ emissions [36]. In this study, there was no difference in the DMI between the diets with higher or lower proportions of legume (Figure 1a), but the lower OM digestibility (1b) of the diet with a higher proportion of legumes and a higher passage rate [12] leaves less time for microorganisms to ferment the feedstuff in the rumen [31]. Therefore, lower $\mathrm{CH}_{4}$ emissions were observed in CVH40 and AH40 than in CVH20 and AH20 (Figure 2c).

In addition to the effects of $\mathrm{LP}$ on $\mathrm{CH}_{4}$ emissions, $\mathrm{LS}$ also affected $\mathrm{CH}_{4}$ emissions, especially on the basis of per kilogram metabolic BW (Table 3). The relatively lower $\mathrm{CH}_{4}$ emissions $\left(\mathrm{g} / \mathrm{kg} \mathrm{BW}^{0.75}\right)$ of the $\mathrm{CVH}$ diet groups as compared to the $\mathrm{AH}$ diet groups at the same $\mathrm{LP}$ (Figure 2c) indicate that $\mathrm{CVH}$ has better potential to inhibit $\mathrm{CH}_{4}$ emissions than $\mathrm{AH}$, especially after forage supply (Figure $2 \mathrm{~d}$,f). This might be due to the lower content of NDF and ADF in CVH than in AH, which is in agreement with Beauchemin [35], who reported that lower $\mathrm{CH}_{4}$ emissions for animals fed legumes could often be explained by the lower fiber content of their diets. Moreover, the production of propionate over acetate in the rumen could also reduce $\mathrm{CH}_{4}$ emissions in the rumen [35]. In this study, these changes in propionate and acetate also confirmed that the acetate molar proportion was lower in the CVH diet groups than in the AH diet groups ( $p<0.05$, Table 5$)$, although there were no differences in the propionate molar proportion (Table 5). The ratio of acetate to propionate was around 4.77 in the $\mathrm{CVH}$ diet groups (Table 5), which was higher than the result of the study by Calabrò et al. [36], who reported a value of 2.28 for an $\mathrm{OH}$ and $\mathrm{CVH}$ mixture diet using an in vitro gas production technique. This could be attributed to differences that may exist in vivo and in vitro. For example, increases of in vivo rumen propionate concentrations were lower than those observed in vitro [37].

Increasing the inclusion of concentrates in the diet, especially starch content, was regarded as another way to reduce $\mathrm{CH}_{4}$ emissions [34,38]. In this study, the $\mathrm{CVH} 40$ and $\mathrm{AH} 40$ diet groups have a relatively higher proportion of maize than the $\mathrm{CVH} 20$ and $\mathrm{AH} 20$ diet groups (Table 2). As a consequence, lower $\mathrm{CH}_{4}$ emissions were observed in the $\mathrm{CVH} 40$ and $\mathrm{AH} 40$ diet groups, even though this value only significantly differed between the CVH20 and CVH40 diet groups per kilogram metabolic BW (Figure 2e). Moreover, $\mathrm{CH}_{4}$ emissions still tended to be lower in the higher proportion of maize diet groups per kilogram DMI, although this was not considered significant (Figure 2e). These results suggest that starch intake could suppress $\mathrm{CH}_{4}$ emissions, in accordance with previous studies $[4,31]$.

\subsection{Energy Balance}

In ruminants, energy is lost in the form of feces, urine, and methane emissions [39]. In this study, FE output and the ratio of FE output to GE intake were greater in the CVH40 and AH40 diet groups than in the CVH20 and AH20 diet groups (Figure 3d). This could be explained by the higher passage rate of the diets with a higher proportion of legumes in the rumen [12], as well as decreased DM digestibility (Figure 1b) because the greater the DM excretion, the greater the FE loss. The ratio of UE output to GE intake, which in previous studies was found to range from $0.9 \%$ to $4.8 \%$ [39,40], is an indispensable element of energy loss, and high UE loss is more common when animals are fed a silage diet [41]. In this study, the mean $1.4 \%$ for the ratio of UE output to GE intake fell within the lower range of the quoted studies, but LP did not significantly influence UE output or the ratio of UE output to GE intake (Figure 3b). The relatively lower values of the ratio of $\mathrm{CH}_{4}$-E to GE intake in the CVH40 and AH40 diet groups could be explained by the lower OM digestibility (Figure 1b), which reduced the retention time of the feedstuff in the rumen.

ME intake, expressed as per kilogram metabolic BW, was higher in the CVH diet groups than in the AH diet groups (Table 3, Figure 3a), which could be attributed to the higher forage DMI in the 
CVH diet groups (Figure 1a) because CVH had a higher ME concentration (MEC) than AH (Table 1). However, no differences were found for the ratio of ME intake to GE intake among the four diet groups (Figure 3a). Nevertheless, the higher ratio of FE output to GE intake in the diet with a higher proportion of legumes (Table 4 and Figure 3d), which accounted for the largest part of the feed energy that could not be utilized by the animals [19], still tended to be lower in the CVH40 and AH40 than in the CVH20 and AH20 diet groups (Figure 3a). Additionally, the ratio of ME intake to GE intake for the crossbred Simmental cattle, in this study, was around 0.67 , which was higher than the previously reported 0.47 for mature Simmental cows [42]. This could be attributed to a higher OM digestibility (averaged $75.4 \%$ ) in this study ascompared to that (62.4\%) in the previous study [42]. The higher ME intake (Table 3 and Figure 3a) alongside a lack of differences in RE (Figure 3f) in the CVH diet groups as compared to the AH diet groups could be attributed to an increased HP for the CVH diet groups than the AH diet groups (Table 4 and Figure 3e). This is consistent with the finding of Ferrell and Jenkins [43] that HP increased alongside increasing ME intake for crossbred beef cattle.

\subsection{N Balance, N Metabolism, and N Utilization Efficiency (NUE)}

$\mathrm{N}$ excretion in feces and urine represents a considerable $\mathrm{N}$ loss from ruminant husbandry $[7,22]$. In this study, N losses were affected by LS and LP, although LS and LP did not influence total N intake (Table 3). For example, the significantly higher FN output and the ratio of FN output to N intake corresponded with a higher proportion of legume (CVH40 vs. CVH20 and AH40 vs. AH20, Figure $4 \mathrm{c}$ ). These were likely caused by the decreased nutrient digestibility (Figure $1 \mathrm{~b}$ ), as well as decreased apparent $\mathrm{N}$ digestibility (Figure 4a), which usually lead to more $\mathrm{N}$ being excreted in feces. As a result, the higher FN output (Figure 4c) (but no different UN output, Figure 4 b) in the diet with a higher proportion of legumes (Figure $4 b$ ) led to a reduced RN in the lower proportion of the legume diets ( $p=0.073$, Table 3, and Figure $4 \mathrm{~d}$ ). The UN, FN, and RN outputs were influenced by LS (Table 3). The UN output in the CVH diet groups was lower than that in the AH diet groups (Figure $4 \mathrm{~b}$ ), whereas the FN output presented an opposite result (Figure 4c). The greater shift of $\mathrm{N}$ excretion from urine to feces in the $\mathrm{CVH}$ diet groups than in the $\mathrm{AH}$ diet groups was regarded as a way to reduce the impact of volatile $\mathrm{N}$ excretion on the environment [6] because urinary urea is rapidly hydrolyzed to ammonium and then converted to ammonia which is readily volatilized and lost from the farm system to the environment [44]. By contrast, fecal ammonia production is generally low due to the slow mineralization rates of organic nitrogenous compounds [3,7]. As a consequence, the $\mathrm{RN}$ in the $\mathrm{CVH}$ diet groups was higher than that in the AH diet groups (Figure $4 \mathrm{~d}$ ). Therefore, the CVH diet has a greater potential to reduce the effects of volatile $\mathrm{N}$ excretions on the environment than the AH diet.

Generally, high ruminal ammonia-N concentrations for optimal OM degradation will result in an increase in the loss of $\mathrm{N}$ through urine [45]. In this study, ammonia- $\mathrm{N}$ concentrations in the rumen tended to be lower with a higher proportion of legumes, especially in AH diets (Figure 4e). This difference could possibly be due to the relatively higher passage rate of feedstuff in the rumen with increasing legume proportions [12], thereby, yielding a lower OM digestibility (Figure 1b) and ammonia-N concentrations in the diets with higher proportions of legumes than in the diets with lower proportions of legumes.

In addition, BUN levels reflected the protein status of cattle and positively corresponded with changes in the ammonia-N concentration in rumen fluid [46]. In this study, BUN tended to be higher in the diets with a higher proportion of legumes (Figure 4f), which was inconsistent with ruminal ammonia-N concentrations (Figure 4e). This might be attributable to the lowest pH in AH40 (Table 5), which depressed the transport of ammonia across the rumen wall. Studies have shown that the permeability of the rumen wall for ammonia is $\mathrm{pH}$ dependent, and has a positive correlation with $\mathrm{pH}$ [47]. Additionally, although the ruminal ammonia-N concentration tended to be lower in the diets with higher proportions of legumes than in the diets with lower proportions of legumes, there was no reduction in BWG (Figure 1c). This suggests that adequate ruminal available $\mathrm{N}$ was provided from the 
diet to maximize microbial fermentation in the rumen under a ruminal ammonia-N concentration of around $4.0 \mathrm{mmol} / \mathrm{L}$.

\section{Conclusions}

The results of this study suggest the following: (1) a higher proportion of legumes in the diet could reduce $\mathrm{CH}_{4}$ emissions and minimize the impact of volatile $\mathrm{N}$ excretion to the environment; (2) increasing legume proportions in the diet could reduce nutrient digestibility, whereas the degree of reduction differs between common vetch hay and alfalfa hay; and (3) common vetch hay has great potential to minimize the negative effects of $\mathrm{CH}_{4}$ emissions and $\mathrm{N}$ excretion into the environment. Therefore, an opportunity for strategic feeding exists by using alfalfa hay (20\%) and common vetch hay (40\%) to reduce the direct impact of volatile $\mathrm{N}$ excretion and $\mathrm{CH}_{4}$ emissions on the environment while maintaining BWG, as well as nutrient digestibility for crossbred Simmental cattle, in dryland environments.

Author Contributions: Conceptualization, A.T., F.H., and T.I.; methodology, A.T., F.H., N.K., T.I., and W.D.; data curation, W.D.; writing — original draft preparation, W.D.; writing—review and editing, F.P., and T.I.; visualization, W.D.; supervision, A.T. and F.P.; project administration, A.T. and F.H.; funding acquisition, A.T. and F.H.

Funding: This research was funded by the Marginal Region Agriculture Project of Tottori University, the Strategic Priority Research Program of Chinese Academy of Sciences of China (grant no. XDA20100102), the National Natural Science Foundation of China (no. 31672472), and the Program for Changjiang Scholars and Innovative Research Team at the University of China (IRT_17R50).

Acknowledgments: The authors thank Chang Shenghua, Zhang Cheng, and the students of the College of Pastoral Agriculture Science and Technology (Lanzhou University, China) for supporting the operation of the respiration chambers and for analyzing the feed, fecal, and urinary samples. The authors also wish to thank the Academician Nan Zhibiao for supporting common vetch seeds (Vicia sativa L.cv. Lanjian No. 3) for this study.

Conflicts of Interest: The authors declare no conflict of interest.

\section{References}

1. National Research Council (NRC). Air Emissions from Animal Feeding Operations: Current Knowledge, Future Needs; National Academies Press: Washington, DC, USA, 2003.

2. Montes, F.; Meinen, R.; Dell, C.; Rotz, A.; Hristov, A.N.; Oh, J.; Waghorn, G.; Gerber, P.J.; Henderson, B.; Makkar, H.P.S.; et al. Special topics-Mitigation of methane and nitrous oxide emissions from animal operations: II. A review of manure management mitigation options. J. Anim. Sci. 2013, 91, 5070-5094. [CrossRef]

3. Kebreab, E.; Dijkstra, J.; Bannink, A.; France, J. Recent advances in modeling nutrient utilization in ruminants. J. Anim. Sci. 2009, 87, E111-E122. [CrossRef] [PubMed]

4. Hristov, A.N.; Oh, J.; Firkins, J.L.; Dijkstra, J.; Kebreab, E.; Waghorn, G.; Makkar, H.P.S.; Adesogan, A.T.; Yang, W.; Lee, C.; et al. Special topics-Mitigation of methane and nitrous oxide emissions from animal operations: I. A review of enteric methane mitigation options. J. Anim. Sci. 2013, 91, 5045-5069. [CrossRef] [PubMed]

5. Dong, L.; Li, B.; Diao, Q. Effects of Dietary Forage Proportion on Feed Intake, Growth Performance, Nutrient Digestibility, and Enteric Methane Emissions of Holstein Heifers at Various Growth Stages. Animals 2019, 9, 725. [CrossRef] [PubMed]

6. Yan, T.; Frost, J.P.; Keady, T.W.J.; Agnew, R.E.; Mayne, C.S. Prediction of nitrogen excretion in feces and urine of beef cattle offered diets containing grass silage. J. Anim. Sci. 2007, 85, 1982-1989. [CrossRef]

7. Waldrip, H.M.; Todd, R.W.; Cole, N.A.H. Prediction of nitrogen excretion by beef cattle: A meta-analysis. J. Anim. Sci. 2013, 91, 4290-4302. [CrossRef]

8. Givens, D.I.; Owen, E.; Omed, H.M.; Axford, R.F.E. Forage Evaluation in Ruminant Nutrition; CABI Publishing: Wallingford, UK, 2000; pp. 9-10.

9. Graham, P.H.; Vance, C.P. Legumes: Importance and constraints to greater use. Plant Physiol. 2003, 131, 872-877. [CrossRef]

10. Abreu, A.; Carulla, J.E.; Lascano, C.E.; Diaz, T.E.; Kreuzer, M.; Hess, H.D. Effects of Sapindus saponaria fruits on ruminal fermentation and duodenal nitrogen flow of sheep fed a tropical grass diet with and without legume. J. Anim. Sci. 2004, 82, 1392-1400. [CrossRef] 
11. Doran, M.P.; Laca, E.A.; Sainz, R.D. Total tract and rumen digestibility of mulberry foliage (Morus alba), alfalfa hay and oat hay in sheep. Anim. Feed. Sci. Technol. 2007, 138, 239-253. [CrossRef]

12. McCaughey, W.P.; Wittenberg, K.; Corrigan, D. Impact of pasture type on methane production by lactating beef cows. Can. J. Anim. Sci. 1999, 79, 221-226. [CrossRef]

13. Wuchen, D.; Fujiang, H.; Atsushi, T.; Kobayashi, N.; Fei, P.; Ichinohe, T. Effects of oat hay and leguminous forage mixture feeding on body weight gain, enteric methane emission and energy utilization in crossbred Simmental male beef cattle. Anim. Sci. J. 2019. under review.

14. Kobayashi, N.; Hou, F.J.; Tsunekawa, A.; Chen, X.J.; Yan, T.; Ichinohe, T. Effects of substituting alfalfa hay for concentrate on energy utilization and feeding cost of crossbred Simmental male calves in Gansu Province, China. Grassl. Sci. 2017, 63, 245-254. [CrossRef]

15. Kobayashi, N.; Hou, F.J.; Tsunekawa, A.; Chen, X.J.; Yan, T.; Ichinohe, T. Appropriate level of alfalfa hay in diets for rearing Simmental crossbred cattle in dryland China. Asian Australas. J. Anim. Sci. 2018, 31, 1881-1889. [CrossRef] [PubMed]

16. Larbi, A.; El-Moneim, A.A.; Nakkoul, H.; Jammal, B.; Hassan, S. Intra-species variations in yield and quality determinants in Vicia species: 3. Common vetch (Vicia sativa ssp. sativa L.). Anim. Feed Sci. Technol. 2011, 164, 241-251. [CrossRef]

17. Rihawi, S.; Iniguez, L.; Knaus, W.F.; Zaklouta, M.; Wurzinger, M.; Soelkner, J.; Larbi, A.; Bomfim, M.A.D. Fattening performance of lambs of different Awassi genotypes, fed under cost-reducing diets and contrasting housing conditions. Small Rumin. Res. 2010, 94, 38-44. [CrossRef]

18. Assefa, G.; Ledin, I. Effect of variety, soil type and fertiliser on the establishment, growth, forage yield, quality and voluntary intake by cattle of oats and vetches cultivated in pure stands and mixtures. Anim. Feed Sci.Technol. 2001, 92, 95-111. [CrossRef]

19. Hernández-Ortega, M.; Heredia-Nava, D.; Espinoza-Ortega, A.; Sánchez-Vera, E.; Arriaga-Jordán, C.M. Effect of silage from ryegrass intercropped with winter or common vetch for grazing dairy cows in small-scale dairy systems in Mexico. Trop. Anim. Health Prod. 2011, 43, 947-954. [CrossRef]

20. Agricultural and Food Research Council. Energy and Protein Requirements of Ruminants. An Advisory Manual Prepared by the AFRC Technical Committee on Responses to Nutrients; Centre for Agriculture and Bioscience International: Wallingford, UK, 1993; pp. 1-38.

21. Chinese Feeding Standard for Beef Cattle (CFSBC). Ministry of Agriculture of the People's Republic of China. 2004. Available online: https://wenku.baidu.com/view/154d59bdf121dd36a32d8269.html (accessed on 4 October 2019).

22. Zhao, Y.G.; Aubry, A.; O'Connell, N.E.; Annett, R.; Yan, T. Effects of breed, sex, and concentrate supplementation on digestibility, enteric methane emissions, and nitrogen utilization efficiency in growing lambs offered fresh grass. J. Anim. Sci. 2015, 93, 5764-5773. [CrossRef]

23. Gerrits, W.; Labussiere, E.; Dijkstra, J.; Reynolds, C.; Metges, C.; Kuhla, B.; Lund, P.; Weisbjerg, M.R. Letter to the Editors: Recovery test results as a prerequisite for publication of gaseous exchange measurements. Animal 2018, 12, 4. [CrossRef]

24. Brouwer, E. Report of sub-committee on constants and factors. In Proceedings of the 3rd Symposium on Energy Metabolism of Farm Animals of European Association for Animal Production; Blaxter, K.L., Ed.; Academic Press: Scotland, UK, 1965.

25. Kohn, R.A.; Dinneen, M.M.; Russek-Cohen, E. Using blood urea nitrogen to predict nitrogen excretion and efficiency of nitrogen utilization in cattle, sheep, goats, horses, pigs, and rats. J. Anim. Sci. 2005, 83, 879-889. [CrossRef]

26. Association of Official Analytical Chemists (AOAC). Official Methods of Analysis of the Association of Official Analytical Chemists, 15th ed; Association of Official Analytical Chemists: Arlington, VA, USA, 1990.

27. Van Soest, P.J.; Robertson, J.B.; Lewis, B.A. Methods for dietary fiber, neutral detergent fiber, and nonstarch polysaccharides in relation to animal nutrition. J. Dairy Sci. 1991, 74, 3583-3597. [CrossRef]

28. Buxton, D.R. Quality-related characteristics of forages as influenced by plant environment and agronomic factors. Anim. Feed Sci. Technol. 1996, 59, 37-49. [CrossRef]

29. Karabulut, A.; Canbolat, O.; Kalkan, H.; Gurbuzol, F.; Sucu, E.; Filya, I. Comparison of in vitro gas production, metabolizable energy, organic matter digestibility and microbial protein production of some legume hays. Asian Australas. J. Anim. Sci. 2007, 20, 517-522. [CrossRef] 
30. Patra, A.K. Effects of supplementing low-quality roughages with tree foliages on digestibility, nitrogen utilization and rumen characteristics in sheep: A meta-analysis. J. Anim. Physiol. Anim. Nutr. 2010, 94, 338-353. [CrossRef] [PubMed]

31. Archimède, H.; Eugène, M.; Marie Magdeleine, C.; Boval, M.; Martin, C.; Morgavi, D.P.; Lecomte, P.; Doreau, M. Comparison of methane production between C3 and C4 grasses and legumes. Anim. Feed Sci. Technol. 2011, 166, 59-64. [CrossRef]

32. Lee, J.M.; Woodward, S.L.; Waghorn, G.C.; Clark, D.A. Methane emissions by dairy cows fed increasing proportions of white clover (Trifolium repens) in pasture. Proc. N. Z. Grassl. Assoc. 2004, 66, 151-155.

33. Guglielmelli, A.; Calabrò, S.; Primi, R.; Carone, F.; Cutrignelli, M.I.; Tudisco, R.; Piccolo, G.; Ronchi, B.; Danieli, P.P. In vitro fermentation patterns and methane production of sainfoin (Onobrychis viciifolia Scop.) hay with different condensed tannin contents. Grass Forage Sci. 2011, 66, 488-500. [CrossRef]

34. Grainger, C.; Beauchemin, K.A. Can enteric methane emissions from ruminants be lowered without lowering their production? Anim. Feed Sci. Technol. 2011, 166, 308-320. [CrossRef]

35. Beauchemin, K.A.; Kreuzer, M.; O’Mara, F.; McAllister, T.A. Nutritional management for enteric methane abatement: A review. Aust. J. Exp. Agric. 2008, 48, 21-27. [CrossRef]

36. Calabrò, S.; Carone, F.; Cutrignelli, M.; D’Urso, S.; Piccolo, G.; Tudisco, R.; Angelino, G.; Infascelli, F. The effect of haymaking on the neutral detergent soluble fraction of two intercropped forages cut at different growth stages. Ital. J. Anim. Sci. 2006, 5, 327-339. [CrossRef]

37. Fievez, V.; Dohme, F.; Danneels, M.; Raes, K.; Demeyer, D. Fish oils as potent rumen methane inhibitors and associated effects on rumen fermentation in vitro and in vivo. Anim. Feed Sci. Technol. 2003, 104, 41-58. [CrossRef]

38. Yan, T.; Agnew, R.E.; Gordon, F.J.; Porter, M.G. Prediction of methane energy output in dairy and beef cattle offered grass silage-based diets. Livest. Prod. Sci. 2000, 64, 253-263. [CrossRef]

39. Chaokaur, A.; Nishida, T.; Phaowphaisal, I.; Sommart, K. Effects of feeding level on methane emissions and energy utilization of Brahman cattle in the tropics. Agric. Ecosyst. Environ. 2015, 199, 225-230. [CrossRef]

40. Zou, C.X.; Lively, F.O.; Wylie, A.R.G.; Yan, T. Estimation of the maintenance energy requirements, methane emissions and nitrogen utilization efficiency of two suckler cow genotypes. Animal 2016, 10, 616-622. [CrossRef]

41. Kirkpatrick, D.E.; Steen, R.W.J.; Unsworth, E.F. The effect of differing forage: Concentrate ratio and restricting feed intake on the energy and nitrogen utilization by beef cattle. Livest. Prod. Sci. 1997, 51, 151-164. [CrossRef]

42. Estermann, B.L.; Sutter, F.; Schlegel, P.O.; Erdin, D.; Wettstein, H.R.; Kreuzer, M. Effect of calf age and dam breed on intake, energy expenditure, and excretion of nitrogen, phosphorus, and methane of beef cows with cattle. J. Anim. Sci. 2002, 80, 1124-1134. [CrossRef]

43. Ferrell, C.L.; Jenkins, T.G. Body composition and energy utilization by steers of diverse genotypes fed a high-concentrate diet during the finishing period: I.; Angus, Belgian Blue, Hereford, and Piedmontese sires. J. Anim. Sci. 1998, 76, 637. [CrossRef]

44. Koenig, K.M.; Beauchemin, K.A. Effect of feeding condensed tannins in high protein finishing diets containing corn distillers grains on ruminal fermentation, nutrient digestibility, and route of nitrogen excretion in beef cattle. J. Anim. Sci. 2018, 96, 4398-4413. [CrossRef]

45. Ipharraguerre, I.R.; Clark, J.H. Varying protein and starch in the diet of dairy cows. II. Effects on performance and nitrogen utilization for milk production. J. Dairy Sci. 2005, 88, 2556-2570. [CrossRef]

46. Dong, R.L.; Zhao, G.Y.; Chai, L.L.; Beauchemin, K.A. Prediction of urinary and fecal nitrogen excretion by beef cattle. J. Anim. Sci. 2014, 92, 4669-4681. [CrossRef]

47. Abdoun, K.; Stumpff, F.; Martens, H. Ammonia and urea transport across the rumen epithelium: A review. Anim. Health Res. Rev. 2006, 7, 43-59. [CrossRef] [PubMed]

(C) 2019 by the authors. Licensee MDPI, Basel, Switzerland. This article is an open access article distributed under the terms and conditions of the Creative Commons Attribution (CC BY) license (http://creativecommons.org/licenses/by/4.0/). 